\title{
Perbandingan Tingkat Akurasi Pengenalan Kadar Semen Dan Pasir Pada Campuran Kering Berdasarkan Tingkat Resolusi Kamera Dengan Metode Pengenalan JST
}

\author{
Erven Tanjungan ${ }^{1}$, Gasim $^{2}$, Sudiadi $^{3}$ \\ ${ }^{1,2,3}$ STMIK Global Informatika MDP; Jl. Rajawali No. 14, \\ ${ }^{1,2}$ Teknik Informatika ${ }^{3}$ Sistem Informasi, Palembang \\ e-mail: *12erven17smile@mhs.mdp.ac.id, ${ }^{2}$ gasim@mdp.ac.id, ${ }^{3}$ sudiadi@mdp.ac.id
}

\begin{abstract}
Abstrak
Pasir dan semen merupakan salah satu material terbesar atau terpenting yang digunakan dalam proses pembangunan pada suatu bangunan atau gedung dan selalu digunakan oleh masyarakat. Masing-masing campuran memiliki takaran pasir dan semennya masing-masing, namun untuk orang biasa sulit untuk membedakan jenis-jenis campuran kering pada bangunan runtuh ataupun bangunan yang belum jadi. Penelitian ini membandingkan tingkat akurasi pengenalan kadar semen dan pasir pada campuran kering berdasarkan tingkat resolusi kamera dengan metode pengenalan Jaringan Saraf Tiruan. Jenis campuran yang digunakan antara lain dengan takaran 1semen 1pasir, 1semen 1,5pasir, 1semen 2pasir, 1semen 2,5pasir, 1semen 3pasir, dan 1semen 3,5pasir. Tingkat resolusi kamera yang digunakan ada 5 antara lain $3 M P, 5 M P, 8 M P, 10 M P, 12 M P$, dan menggunakan jarak pemotretan $\pm 9 \mathrm{~cm}$. Metode pengenalan menggunakan Jaringan Syaraf Tiruan dan ekstrasi fitur menggunakan GLCM(Gray Level Co-Occurrence Matrix) yang terdiri dari Entropy, Standard Deviation, Contrast, Angular Second Moment(ASM)/ Homogeneity, Correlation, dan Inverse Different Moment(IDM)/ Energy. Hasil perhitungan tertinggi dalam pengenalan jenis campuran kering berdasarkan tingkat resolusi kamera ialah pada resolusi kamera 12MP dengan jumlah pengenalan sebanyak 105 dari 120 data uji, sehingga menghasilkan tingkat akurasi sebesar $87,5 \%$.
\end{abstract}

Kata kunci-Pasir, Semen, GLCM, Jaringan Syaraf Tiruan.

\begin{abstract}
Sand and cement are one of the largest or most important materials used in the construction process of a building or building and are always used by the community. Each mixture has its own proportions of sand and cement, but for ordinary people it is difficult to distinguish between the types of dry mixtures in collapsed buildings or unfinished buildings. This study compared the accuracy rate of recognition of cement and sand content in dry mixtures based on the level of camera resolution with the Artificial Neural Network recognition method. The types of mixtures used include 1sement 1 sand, 1 cement 1.5 sand, 1 cement 2 sand, 1 cement 2.5 sand, 1 cement 3 sand, and 1 cement 3,5 sand. There are 5 levels of camera resolution used, including $3 M P, 5 M P, 8 M P, 10 M P, 12 M P$, and uses a shooting distance of \pm $9 \mathrm{~cm}$. The recognition method uses Artificial Neural Networks and feature extraction uses GLCM (Gray Level Co-Occurrence Matrix) which consists of Entropy, Standard Deviation, Contrast, Angular Second Moment (ASM) / Homogeneity, Correlation, and Inverse Different Moment (IDM) / Energy. The highest calculation result in the introduction of dry mix types based on the level of camera resolution is the 12MP camera resolution with the number of recognition as much as 105 out of 120 test data, resulting in an accuracy rate of $87.5 \%$.
\end{abstract}

Keywords - Sand, Cement, GLCM, Artificial Neural Networks. 


\section{PENDAHULUAN}

P sir merupakan salah satu bahan yang digunakan untuk campuran bangunan yang berfungsi sebagai bahan pengisi dalam campuran. Walaupun pasir hanya berfungsi sebagai bahan pengisi akan tetapi pasir sangat berpengaruh terhadap sifat-sifat mortar ataupun beton, sehingga pemilihan pasir merupakan suatu bagian penting dalam pembuatan beton ataupun mortar. Semen juga merupakan salah satu bahan campuran, yang berfungsi sebagai perekat antar agregat dan juga sebagai bahan pengisi. Saat ini banyak sekali pabrik semen di Indonesia dengan bermacam-macam merk dan jenis yang dijual dipasaran. Hal ini juga akan mempengaruhi mutu [1].

Takaran dalam mencampurkan pasir dan semen memiliki komposisi campuran pasir yang berbeda-beda. Terdapat 3 jenis campuran dalam dunia konstruksi, antara lain campuran pasir dengan bahan bangunan semen untuk pasangan bata dengan takaran 1:4 dan 1:6, campuran pasir dengan bahan bangunan semen untuk plesteran dinding dengan takaran 4:1 dan 6:1, campuran pasir dengan bahan bangunan semen dan batu split untuk beton dengan takaran 1:2:3 dan 1:1,5:2,5 (www.sementigaroda.com).

Campuran material bangunan dapat diketahui komposisinya sebelum bahan-bahan dicampurkan untuk diaduk. Namun untuk campuran yang sudah mengering, seperti sisa-sisa bangunan yang sudah mengering yang tidak terpakai dan bangunan runtuh sulit untuk diketahui. Kandungan pasir dan semen pada campuran kering tersebut dapat diketahui dengan menelitinya di uji laboratorium oleh ahlinya. Campuran kering tersebut memiliki tekstur masing-masing berdasarkan banyaknya kandungan yang ditambahkan, namun secara kasat mata campuran keras tersebut sulit untuk diketahui.

Metode yang dapat digunakan untuk mengidentifikasi atau mengenali suatu objek dalam suatu penelitian salah satunya adalah Jaringan Saraf Tiruan (JST). Dalam JST, inputan akan menggunakan nilai tekstur yang telah di ekstraksi dari citra. Ekstraksi citra dapat dilakukan berdasarkan tekstur, warna, bentuk, ukuran, dan masih banyak lagi. Ekstraksi ciri yang bisa digunakan salah satunya adalah menggunakan GLCM (Gray Level Co-Occurrence Matrix). Pengambilan citra atau gambar dapat dipengaruhi atau dibandingkan berdasarkan tingkat pencahayaan, resolusi kamera, jarak potret, dan masih banyak lagi.

Penelitian terdahulu yang dilakukan oleh Gasim dan Sudiadi (2015) mengenai Identifikasi Kadar Semen dan Pasir Dalam Campuran Kering Menggunakan Metode Backpropagation. Penelitian ini menggunakan campuran semen dan pasir yang sudah mengeras lalu diteliti kandungannya berdasarkan tekstur. Campuran kering dibuat dengan 6 jenis campuran dengan masing-masing campuran terdiri dari 3 balok, jadi jumlah campuran kering yang dibuat sebanyak 18 balok, 12 balok digunakan untuk data latih (300 citra latih)) dan 6 balok untuk data uji(150 citra uji). Ekstraksi ciri citra yang digunakan adalah dengan mengubah citra RGB menjadi citra Grayscale, lalu selanjutnya menggunakan ciri entropi, standar deviasi, kontras, homogenitas, korelasi, energy. Data latih tersebut akan digunakan sebagai input JST. Selanjutnya pengidentifikasian data uji menggunakan Jaringan Saraf Tiruan Backpropagation dan menghasilkan tingkat akurasi sebesar 87,33\%.

Penelitian terdahulu yang dilakukan oleh Gasim, Sudiadi, Desy Iba Ricoida, Rusbandi, dan Rizani Teguh [2] mengenai Identifikasi Kadar Semen dan Pasir Melalui Citra Permukaan Menggunakan Teknik Blok Citra. Penelitian ini membuat campuran kering yang sama dengan penelitian sebelumnya, namun ada perbedaan pada saat melakukan ekstraksi ciri citra. Ekstraksi ciri dengan 600 citra latih dan 120 citra uji, masing-masing jenis campuran kering dilakukan ekstraksi dengan membagi citra RGB berukuran 500x500 pixel menjadi 4 blok. Selanjutnya citra RGB tersebut diubah menjadi citra Grayscale, dilanjutkan pembentukan matriks LBP, mean, standar deviasi, entropy, skweness, dan kurtosis. Nilai dari ekstraksi ciri data latih akan dijadikan input pada proses JST. Dari JST Backpropagation dilakukan pengidentifikasian data uji yang menghasilkan tingkat akurasi sebesar $80 \%$.

Tanjungan, et., al (Perbandingan Tingkat Akurasi Pengenalan Kadar Semen dan Pasir pada Campuran Kering Berdasarkan Tingkat Resolusi Kamera Dengan Metode Pengenalan JST) 
Penelitian terdahulu yang dilakukan oleh Kelvin Bun dan Hurnaningsih [3], membahas mengenai Identifikasi Telur Retak Menggunakan Metode Jaringan Syaraf Tiruan Berdasarkan Tekstur Telur. Penelitian ini mengidentifikasi telur retak dengan membuat 2 kategori, yaitu telar retak dan telur belum retak. Citra yang diambil akan melalui proses pengolahan citra, analisis citra, dan yang terakhir melakukan pelatihan data citra. Dengan mengidentifikasi telur retak berdasarkan tekstur telur menggunakan Jaringan Syaraf Tiruan, menghasilkan tingkat akurasi yang diperoleh sebesar $80 \%$ berdasarkan 40 data yang telah diuji dengan epoch 5000 dan performance 0,03 .

Penelitian yang dilakukan oleh Raynaldi, Ade, Bayu, dan Kusrini [4], membahas mengenai Deteksi Motif Batik Menggunakan Ekstrasi Tekstur dan Jaringan Syaraf Tiruan. Penelitian ini menggunakan metode esktraksi fitur berupa Discrete Wavelet Transform (DWT), Gray Level Co-Occurrence matrix (GLCM), dan Local Binary Pattern (LBP). Pengujian dilakukan dengan membandingkan dua kelompok fitur: DWT-GLCM dan DWT-GLCM-LBP untuk mengetahui metode ekstraksi fitur yang lebih baik dalam deteksi motif batik. Metode pengujian yang digunakan adalah K-Fold Cross Validation dengan hasil berupa confusion matriks untuk kemudian dihitung nilai akurasi dan F-Measure-nya. Hasil pengujian menunjukkan bahwa penggunaan ekstraksi fitur tekstur DWT-GLCM-LBP mampu mencapai akurasi 74\% dengan jenis dekomposisi Daubechies 4 level 3.

Penelitian yang dilakukan oleh Achmad, Rizal, dan Dian [5], membahas mengenai Identifikasi Tanda-Tangan Menggunakan Jaringan Saraf Tiruan Perambatan-Balik (Backpropagation). Citra yang telah melewati tahap segmentasi akan dilakukan ekstraksi ciriciri tertentu dengan membagi citra menjadi beberapa baris $\mathrm{M}$ dan kolom $\mathrm{N}$ seperti kotak. Kotak yang memiliki angka 1 diartikan kotak tersebut dilewati oleh garis tanda-tangan, sedangkan untuk angka 0 berarti kotak tersebut tidak dilewati. Penelitan ini menghasilkan tingkat akurasi sebesar $95 \%$ dalam mengenali tanda-tangan yang telah dilatihkan sebelumnya dan $88 \%$ dalam mengenali tanda-tangan dari data luar atau data baru.

\section{METODE PENELITIAN}

Berikut ini adalah tahapan-tahapan yang dilakukan oleh peneliti dalam melakukan tahapan penelitian Perbandingan Tingkat Akurasi Penganalan Kadar Semen dan Pasir Pada Campuran Kering Berdasarkan Tingkat Resolusi Kamera Dengan Metode Pengenalan Jaringan Syaraf Tiruan. Tahapan ini digambarkan dalam bentuk bagan kerangka tahapan penelitian yang disajikan pada gambar 1.

Tanjungan, et., al (Perbandingan Tingkat Akurasi Pengenalan Kadar Semen dan Pasir pada Campuran Kering Berdasarkan Tingkat Resolusi Kamera Dengan Metode Pengenalan JST) 


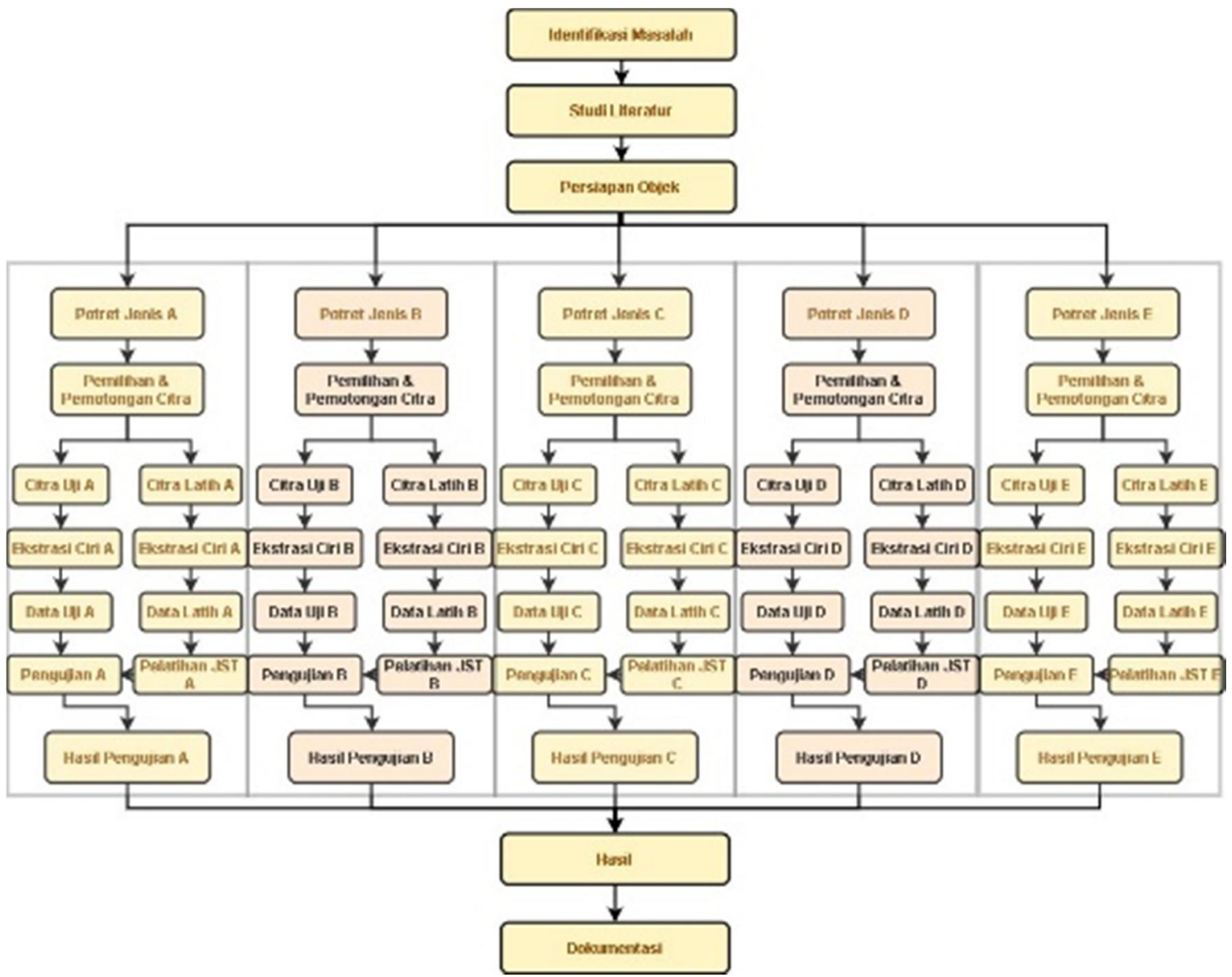

Gambar 1. Kerangka Tahapan Penelitian

\subsection{Identifikasi Masalah}

Tahap ini melakukan identifikasi masalah penelitian mengenai perbandingan tingkat akurasi pengenalan kadar semen dan pasir pada campuran kering berdasarkan tingkat resolusi kamera.

\section{2 Persiapan Objek}

Tahap ini melakukan persiapan objek campuran kering, Gambar 2 merupakan bahan dan alat yang digunakan selama proses pembuatan.

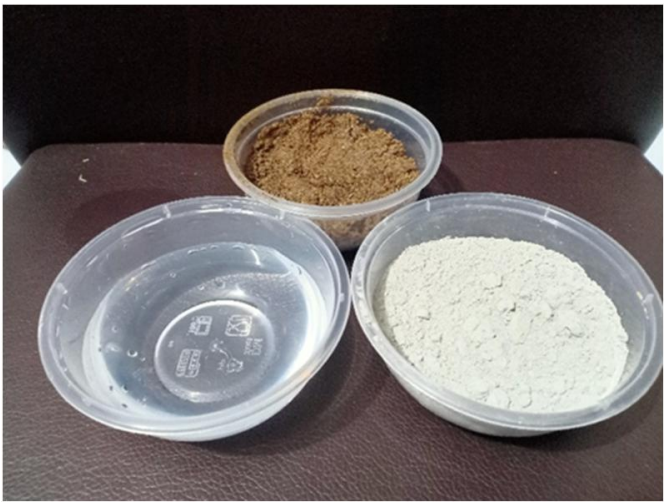

Gambar 2. Bahan dan Alat Membuat Campuran Kering

Tanjungan, et., al (Perbandingan Tingkat Akurasi Pengenalan Kadar Semen dan Pasir pada Campuran Kering Berdasarkan Tingkat Resolusi Kamera Dengan Metode Pengenalan JST) 
Penelitian ini menggunakan semen dengan merek semen tiga roda, pasir, dan air, sedangkan untuk alatnya menggunakan sterofom untuk wadah makanan sebagai tempat pembentukan campuran kering. Mangkuk plastik juga digunakan sebagai wadah takaran.
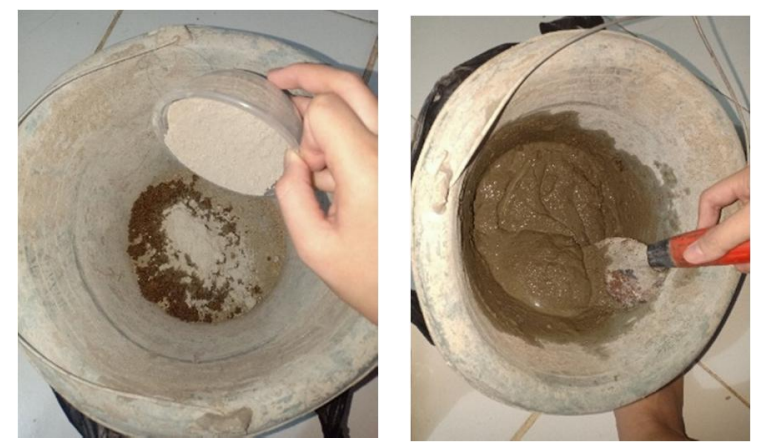

Gambar 3. Proses Pembuatan Campuran Kering (1)

\section{3 Potret jenis A, B, C,D,E, dan $F$}

Tahap ini melakukan pemotretan objek pada masing-masing campuran dengan tingkat resolusi yang berbeda-beda dengan jarak $9 \mathrm{~cm}$. Potret jenis A ditujukan untuk pemotretan menggunakan resolusi kamera sebesar 3MP, potret jenis B ditujukan untuk pemotretan menggunakan resolusi kamera sebesar 5MP, potret jenis $\mathrm{C}$ ditujukan untuk pemotretan menggunakan resolusi kamera sebesar $8 \mathrm{MP}$, potret jenis $\mathrm{D}$ ditujukan untuk pemotretan menggunakan resolusi kamera sebesar 10MP, potret jenis $\mathrm{E}$ ditujukan untuk pemotretan menggunakan resolusi kamera sebesar 12MP.

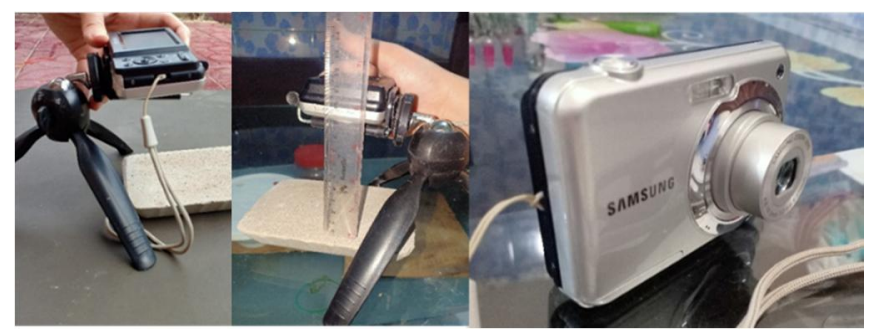

(A)

(B)

Gambar 4. Jarak Potret

Gambar 4(A) merupakan pemotretan yang dilakukan dengan jarak $9 \mathrm{~cm}$, resolusi kamera 3MP, 5MP, 8MP, 10MP, dan 12MP, campuran kering yang digunakan sebagai objek penelitian dan tripod untuk memudahkan pengambilan foto. Gambar 4(B) merupakan kamera Samsung ES9 yang digunakan untuk pemotretan, salah satu contohnya yang dipotret dapat dilihat pada Gambar 5.

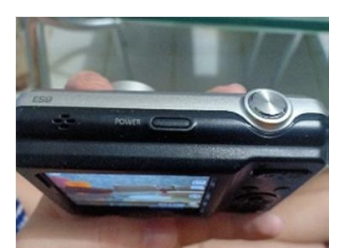

(A)

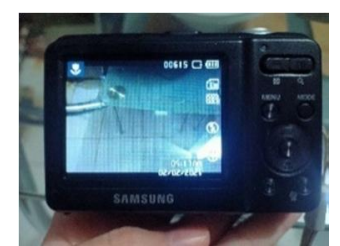

(B)

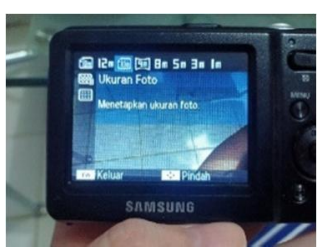

(C)

Gambar 5. Cara Mengubah Resolusi pada Kamera Samsung ES9

Gambar 5 merupakan gambar cara penggunaan kamera untuk mengubah resolusi kamera. Pada Gambar 5 (A), dengan menekan power yang berada pada bagian tengah dapat

Tanjungan, et., al (Perbandingan Tingkat Akurasi Pengenalan Kadar Semen dan Pasir pada Campuran Kering Berdasarkan Tingkat Resolusi Kamera Dengan Metode Pengenalan JST) 
menyalakan kamera dan untuk tombol bulat pada kanan kamera merupakan tombol untuk mengambil gambar. Pada Gambar 5 (B) merupakan tampilan saat kamera dinyalakan, terdapat beberapa tombol pada bagian kanan kamera yang memiliki fungsinya masing-masing. Pada Gambar 5 (C), ), selanjutnya pilih resolusi kamera yang diinginkan misalnya pada penelitian ini resosolusi kamera yang diperlukan antara lain 3MP, 5MP, 8MP, 10MP, dan 12MP dan salah satu contohnya yang dipotret dapat dilihat pada Gambar 6.

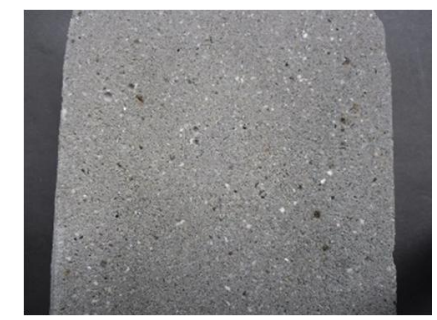

Gambar 6. Contoh Hasil Potret Resolusi Kamera 3 MP

\section{4. Pemilihan dan Pemotongan Citra}

Tahap ini melakukan pemilihan citra dari hasil pemotretan yang telah dilakukan sebelumnya. Pemilihan dilakukan untuk menyingkirkan hasil foto yang tidak diinginkan seperti kabur, buram, gelap, dan lainnya. Pemotongan citra merupakan tahap setelah menyingkirkan semua citra yang tidak diinginkan. Citra hasil pemotretan di potong (crop) dengan ukuran 500x500 (berdasarkan penelitian sebelumnya). Pemotongan citra menggunakan perangkat lunak Microsoft Office 2010.

\section{5. Citra Uji dan Citra Latih}

Pada tahap ini dilakukan pembagian citra yang sudah dikumpulkan sebelumnya, citra akan dibagi menjadi citra uji dan citra latih berdasarkan masing-masing jenis resolusi kemera. Jumlah citra untuk 1 jenis resolsui kamera diperoleh sebanyak 450 citra latih dan 120 citra uji. Sehingga untuk total citra keseluruhan diperoleh sebanyak 2250 citra latih dan 600 citra uji.

\section{6. Ekstrasi Ciri}

Pada tahap ini, citra latih dan uji akan dilakukan ekstrasi ciri citra. Masing-masing jenis citra akan diubah dari data citra RGB menjadi citra grayscale, selanjutnya ekstrasi ciri akan menggunakan Gray Level Co-occurance Matrix (GLCM) dengan menghitung ciri, antara lain Entropy, Standard Deviation, Contrast, Angular Second Moment (ASM)/ Homogeneity, Correlation, dan Inverse Different Moment (IDM)/ Energy, yang dimana nilai tersebut digunakan sebagai parameter input kedalam jaringan syaraf tiruan.

\section{7. Klasifikasi dan Pelatihan JST}

Pada tahap ini peneliti akan menggunakan Jaringan Saraf Tiruan dengan melakukan pelatihan JST terhadap data latih yang sudah diekstrasi sehingga mampu mengidentifikasikan jenis campuran terhadap data uji. Hasil output yang diperoleh dari pelatihan JST akan digunakan untuk proses uji pengenalan. Terdapat target yang ingin dicapai berdasarkan data latih yang digunakan pada pelatihan jaringan syaraf tiruan sebagai output, tabel target dapat dilihat pada Tabel 1. 
Tabel 1. Definisi Target

\begin{tabular}{|c|c|c|c|c|c|c|c|}
\hline \multirow{2}{*}{\multicolumn{2}{|c|}{$\begin{array}{l}\text { CAMPURAN } \\
\text { KERING }\end{array}$}} & \multicolumn{6}{|c|}{ TARGET } \\
\hline & & \multirow{2}{*}{$\begin{array}{c}\text { Jenis } 1 \\
-1 \\
1\end{array}$} & \multirow{2}{*}{$\begin{array}{c}\text { Jenis } 1 \text { - } \\
1,5 \\
\mathbf{0}\end{array}$} & \multirow{2}{*}{$\begin{array}{c}\text { Jenis } 1 \text { - } \\
2 \\
\mathbf{0}\end{array}$} & \multirow{2}{*}{$\begin{array}{c}\text { Jenis } 1 \text { - } \\
2,5 \\
0\end{array}$} & \multirow{2}{*}{$\begin{array}{c}\text { Jenis } 1 \\
-3 \\
\mathbf{0}\end{array}$} & \multirow{2}{*}{$\begin{array}{c}\text { Jenis 1 - } \\
\mathbf{3 , 5} \\
\mathbf{0}\end{array}$} \\
\hline \multirow{6}{*}{ OBJEK } & Jenis 1 - 1 & & & & & & \\
\hline & $\begin{array}{c}\text { Jenis } 1 \text { - } \\
1,5\end{array}$ & $\mathbf{0}$ & 1 & $\mathbf{0}$ & $\mathbf{0}$ & $\mathbf{0}$ & $\mathbf{0}$ \\
\hline & Jenis 1 - 2 & $\mathbf{0}$ & $\mathbf{0}$ & 1 & $\mathbf{0}$ & $\mathbf{0}$ & $\mathbf{0}$ \\
\hline & $\begin{array}{c}\text { Jenis } 1 \text { - } \\
2,5\end{array}$ & $\mathbf{0}$ & $\mathbf{0}$ & $\mathbf{0}$ & 1 & $\mathbf{0}$ & $\mathbf{0}$ \\
\hline & Jenis $1-3$ & $\mathbf{0}$ & $\mathbf{0}$ & $\mathbf{0}$ & $\mathbf{0}$ & 1 & $\mathbf{0}$ \\
\hline & $\begin{array}{c}\text { Jenis } 1 \text { - } \\
3,5\end{array}$ & $\mathbf{0}$ & $\mathbf{0}$ & $\mathbf{0}$ & $\mathbf{0}$ & $\mathbf{0}$ & 1 \\
\hline \multicolumn{2}{|c|}{ RENTANG } & $(1-75)$ & $(76-150)$ & $\begin{array}{l}(151- \\
225)\end{array}$ & $\begin{array}{l}(226- \\
300)\end{array}$ & $\begin{array}{l}301- \\
375)\end{array}$ & $\begin{array}{l}(376- \\
450)\end{array}$ \\
\hline
\end{tabular}

\section{HASIL DAN PEMBAHASAN}

\section{1. Implementasi Ekstrasi Fitur}

Tahap ini melakukan ekstrasi ciri dengan menggunakan nilai dari GLCM (Gray Level Co-Occurrence Matrix) terhadap citra uji dan citra latih. Untuk nilai ekstrasi citra latih disimpan dengan menggunakan nama "latihN" dan nilai ekstrasi citra uji disimpan dengan menggunakan nama "ujiN". Masing-masing memiliki 6 nilai yang terdiri dari nilai Entropy, Standard Deviation, Contrast, Angular Second Moment (ASM)/ Homogeneity, Correlation, dan Inverse Different Moment(IDM)/ Energy. Hasil ekstrasi fitur GLCM dapat dilihat pada Gambar 7.

\begin{tabular}{|c|c|c|c|c|c|c|c|c|c|c|c|}
\hline \multicolumn{12}{|c|}{$\boxplus 6 \times 450$ double } \\
\hline & 1 & 2 & 3 & 4 & 5 & 6 & 7 & 8 & 9 & 10 & 11 \\
\hline 1 & -0.2765 & 0.0285 & 0.0266 & -0.3582 & 0.2080 & -0.5156 & -0.2306 & -0.4026 & -0.1190 & -0.8470 & $-0.2 ، \Delta$ \\
\hline 2 & 0.0393 & 0.2408 & 0.2542 & -0.0916 & 0.4870 & -0.3420 & -0.0499 & -0.1824 & 0.2010 & -0.7431 & 0.08 \\
\hline 3 & -0.3194 & 0.5226 & 0.5149 & -0.1332 & 0.3839 & -0.1990 & 0.4958 & -0.0270 & -0.3540 & -0.5437 & $-0.0\}$ \\
\hline 4 & 0.2035 & -0.6185 & -0.6204 & -0.0337 & -0.4992 & 0.0851 & -0.5709 & -0.1160 & 0.2064 & 0.4582 & $-0.0 \hat{x}$ \\
\hline 5 & 0.1929 & -0.4587 & -0.4437 & -0.2084 & -0.0025 & -0.4326 & -0.8801 & -0.4448 & 0.4655 & -0.2834 & -0.0 s \\
\hline 6 & -0.3781 & -0.5994 & -0.6473 & -0.3267 & -0.7326 & -0.0119 & -0.4299 & -0.2417 & -0.4881 & -0.0158 & -0.4 ? \\
\hline
\end{tabular}

Gambar 7. Grafik perbandingan

Gambar 7, menampilkan hasil ekstrasi fitur GLCM pada seluruh citra yang berjumlah 450 citra dengan menggunakan aplikasi MATLAB. Pada baris pertama merupakan nilai Standard Deviation dari semua citra, baris kedua merupakan nilai Entropy dari semua citra, baris ketiga merupakan nilai Contrast dari semua citra, baris keempat merupakan nilai Homogensity (IDM) dari semua citra, baris kelima merupakan nilai Correlation dari semua citra, dan baris keenam merupakan nilai Energy (ASM) dari semua citra. Terdapat 450 kolom, 75 kolom pertama untuk jenis campuran 1 semen 1 pasir, 75 kolom selanjutnya untuk jenis campuran 1 semen 1,5 semen, 75 kolom selanjutnya untuk jenis campuran 1 semen 2 semen, 75 kolom selanjutnya untuk jenis campuran 1 semen 2,5 semen, 75 kolom selanjutnya untuk jenis campuran 1 semen 3 semen, 75 kolom selanjutnya untuk jenis campuran 1 semen 3,5 semen.

\footnotetext{
Tanjungan, et., al (Perbandingan Tingkat Akurasi Pengenalan Kadar Semen dan Pasir pada Campuran Kering Berdasarkan Tingkat Resolusi Kamera Dengan Metode Pengenalan JST)
} 
Jurnal Algoritme

Vol. 1, No. 2, April 2021, Hal. 168-183

\subsubsection{Implementasi Model Jaringan Syaraf Tiruan}

Pada tahap ini, peneliti melakukan pelatihan JST(Jaringan Syaraf Tiruan) dengan menggunakan aplikasi MATLAB terhadap data latih sehingga JST dapat mengenali data latih.

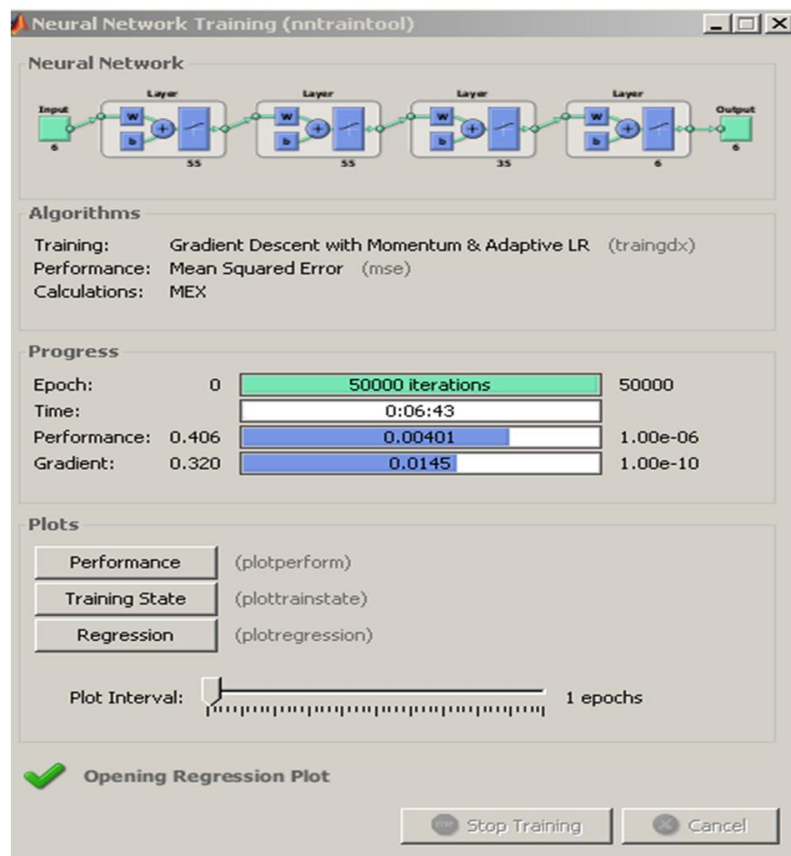

Gambar 8. Pelatihan Model JST

Gambar 8 merupakan hasil training pada 3 layer $(55,55,45)$ dengan menggunakan nilai epochs sebesar 50000, goal sebesar 1e-6, Ir sebesar 0.01, mc sebesar 0,1, min_grade sebesar 1e10, delta sebesar 1e-10, dan min_step sebesar 0,001. Hasil training pada JST dapat dilihat pada Gambar 9 hingga Gambar 10.

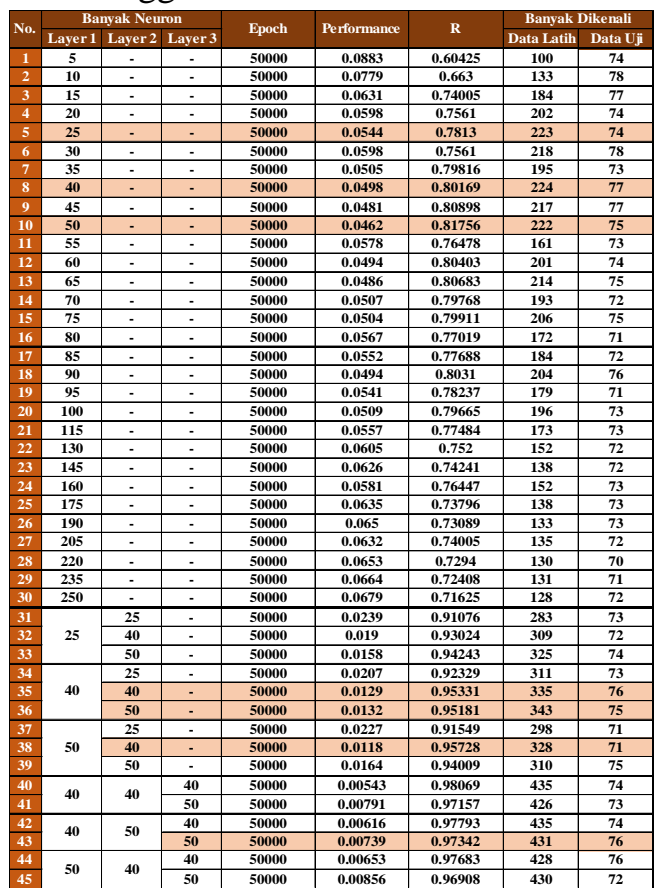

(A) $3 \mathrm{MP}$

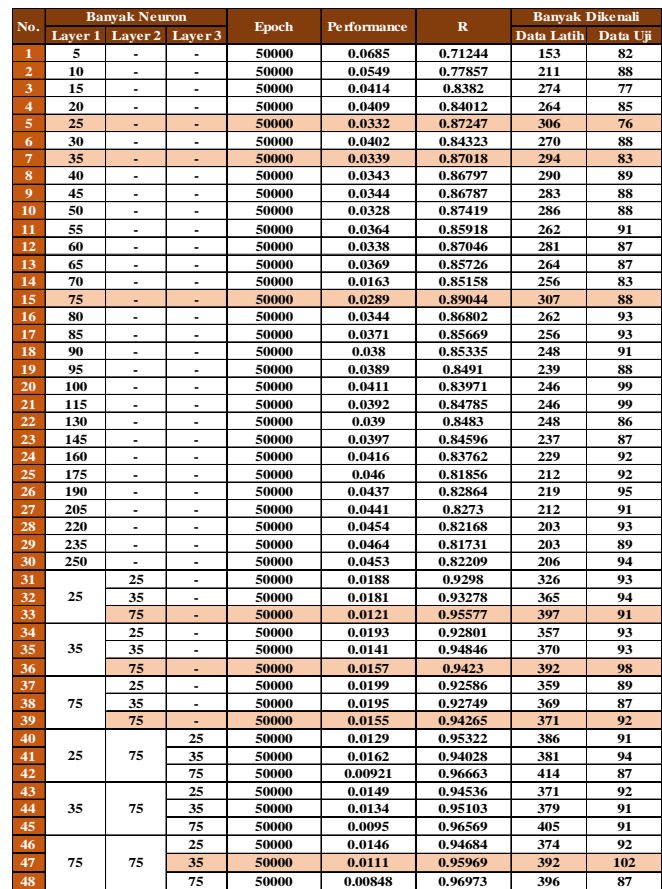

(B) $5 \mathrm{MP}$

Gambar 9. History JST

Tanjungan, et., al (Perbandingan Tingkat Akurasi Pengenalan Kadar Semen dan Pasir pada Campuran Kering Berdasarkan Tingkat Resolusi Kamera Dengan Metode Pengenalan JST) 


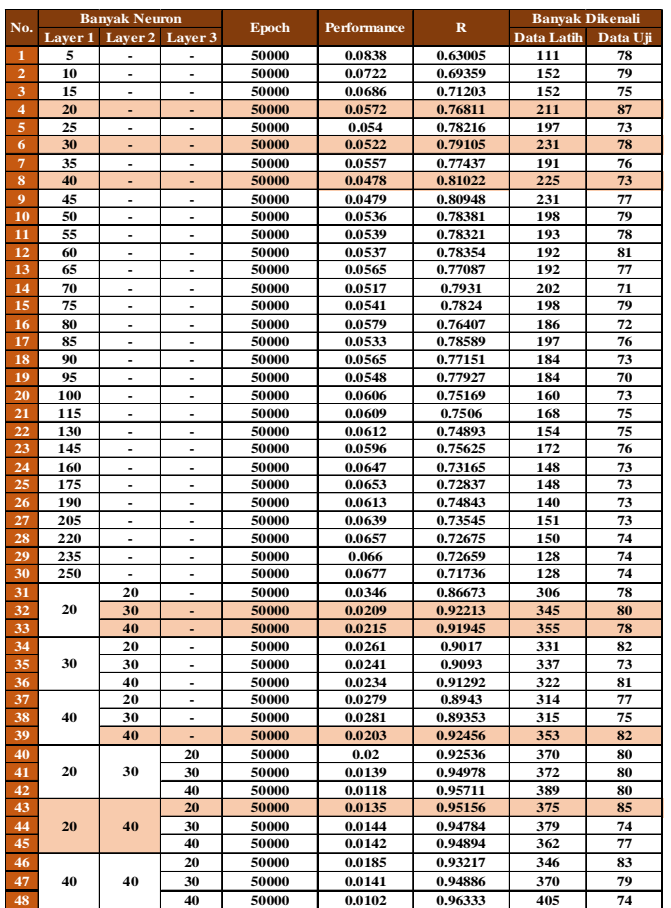

(C) $8 \mathrm{MP}$

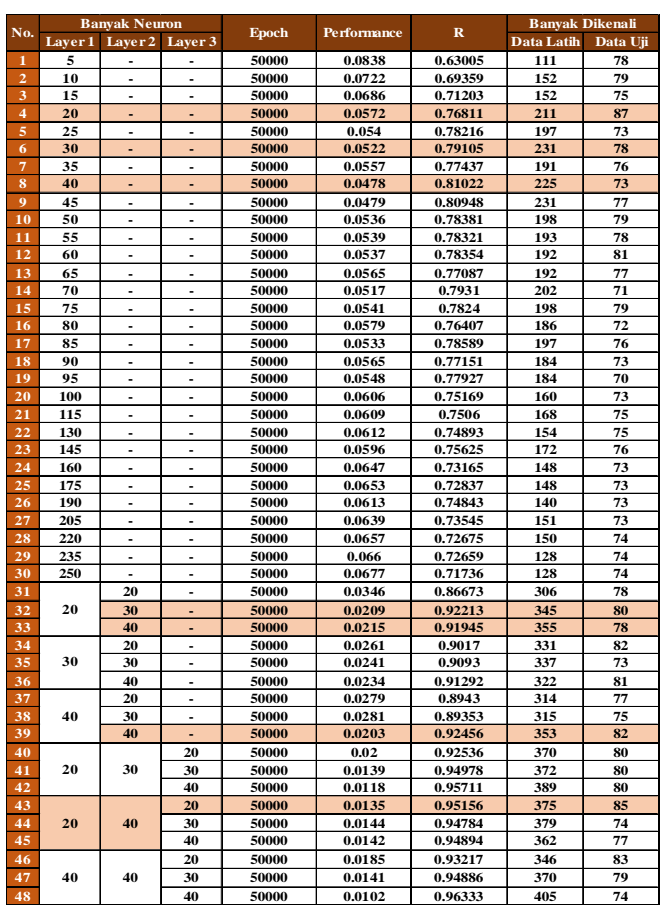

(D) $10 \mathrm{MP}$

Gambar 10. History JST

\begin{tabular}{|c|c|c|c|c|c|c|c|c|}
\hline \multirow{2}{*}{ No. } & \multicolumn{3}{|c|}{ Banyak Neuron } & \multirow{2}{*}{ Epoch } & \multirow{2}{*}{ Performance } & \multirow{2}{*}{$\mathbf{R}$} & \multicolumn{2}{|c|}{ Banyak Dikenali } \\
\hline & Layer 1 & Layer 2 & Layer 3 & & & & Data Latih & Data Uji \\
\hline 1 & 5 & - & - & 50000 & 0.0668 & 0.72162 & 178 & 83 \\
\hline 2 & 10 & - & - & 50000 & 0.0461 & 0.81775 & 230 & 85 \\
\hline 3 & 15 & - & - & 50000 & 0.0407 & 0.84132 & 260 & 83 \\
\hline 4 & 20 & - & - & 50000 & 0.034 & 0.86903 & 279 & 94 \\
\hline 5 & 25 & - & - & 50000 & $\mathbf{0 . 0 3 4 7}$ & 0.86627 & 271 & 80 \\
\hline 6 & 30 & - & - & 50000 & 0.0308 & $\mathbf{0 . 8 8 2 3 9}$ & 284 & 92 \\
\hline 7 & 35 & - & - & 50000 & 0.0286 & 0.89109 & 296 & 85 \\
\hline 8 & 40 & - & - & 50000 & 0.0309 & 0.88209 & 278 & 83 \\
\hline 9 & 45 & - & - & 50000 & 0.0259 & 0.90236 & 309 & 91 \\
\hline 10 & 50 & - & - & 50000 & 0.0298 & 0.8867 & 288 & 80 \\
\hline 11 & 55 & - & - & 50000 & 0.0307 & 0.88255 & 298 & 84 \\
\hline 12 & 60 & - & - & 50000 & 0.0292 & 0.88941 & 292 & 84 \\
\hline 13 & 65 & - & - & 50000 & 0.0309 & 0.88252 & 273 & 87 \\
\hline 14 & 70 & - & - & 50000 & 0.0319 & 0.87805 & 269 & 85 \\
\hline 15 & 75 & - & - & 50000 & $\mathbf{0 . 0 3 0 7}$ & \begin{tabular}{|l|}
$\mathbf{0 . 8 8 3 2}$ \\
\end{tabular} & 289 & 83 \\
\hline 16 & 80 & - & - & 50000 & 0.0317 & 0.87924 & 269 & 86 \\
\hline 17 & 85 & - & - & 50000 & 0.0343 & 0.86838 & 259 & 82 \\
\hline 18 & 90 & - & - & 50000 & 0.0341 & 0.86905 & 260 & 81 \\
\hline 19 & 95 & - & - & 50000 & 0.0329 & 0.87445 & 251 & 84 \\
\hline 20 & 100 & - & - & 50000 & 0.0311 & 0.88169 & 279 & 83 \\
\hline 21 & 115 & - & - & 50000 & 0.0365 & 0.85935 & 244 & 81 \\
\hline 22 & 130 & - & - & 50000 & 0.0376 & 0.85457 & 242 & 81 \\
\hline 23 & 145 & - & - & 50000 & 0.0382 & 0.85246 & 229 & 80 \\
\hline 24 & 160 & - & - & 50000 & 0.0392 & 0.84845 & 219 & 78 \\
\hline 25 & 175 & - & - & 50000 & 0.0398 & 0.84559 & 226 & 81 \\
\hline 26 & 190 & - & - & 50000 & 0.0389 & 0.84974 & 219 & 80 \\
\hline 27 & 205 & - & - & 50000 & 0.0426 & 0.83346 & 208 & 78 \\
\hline 28 & 220 & - & - & 50000 & 0.0419 & 0.83649 & 213 & 76 \\
\hline 29 & 235 & - & - & 50000 & 0.0423 & 0.83467 & 211 & 76 \\
\hline 30 & 250 & - & - & 50000 & 0.0443 & \begin{tabular}{|l}
0.82629 \\
\end{tabular} & 195 & 76 \\
\hline 31 & & 35 & - & 50000 & 0.0069 & 0.97579 & 432 & 97 \\
\hline 32 & 35 & 45 & - & 50000 & 0.0105 & 0.9619 & 403 & 101 \\
\hline 33 & & 55 & - & 50000 & 0.0082 & 0.97028 & 421 & 94 \\
\hline 34 & & 35 & - & 50000 & 0.00482 & 0.98277 & 431 & 92 \\
\hline 35 & 45 & 45 & - & 50000 & 0.0102 & 0.96284 & 400 & 94 \\
\hline 36 & & 55 & - & 50000 & 0.0082 & 0.97027 & 426 & 92 \\
\hline 37 & & 35 & - & 50000 & 0.008 & 0.97096 & 429 & 97 \\
\hline 38 & 55 & 45 & - & 50000 & 0.00789 & 0.97131 & 429 & 96 \\
\hline 39 & & 55 & - & 50000 & 0.00535 & 0.98063 & 438 & 96 \\
\hline 40 & & & 35 & 50000 & 0.00365 & 0.98706 & 437 & 101 \\
\hline 41 & 35 & 35 & 45 & 50000 & 0.00691 & 0.97501 & 430 & 101 \\
\hline 42 & & & 55 & 50000 & 0.00558 & \begin{tabular}{|l}
0.97999 \\
\end{tabular} & 433 & 97 \\
\hline 43 & & & 35 & 50000 & 0.00572 & 0.97937 & 434 & 97 \\
\hline 44 & 45 & 35 & 45 & 50000 & 0.00531 & 0.98094 & 435 & 102 \\
\hline 45 & & & 55 & 50000 & 0.00335 & 0.98797 & 443 & 94 \\
\hline 46 & & & 35 & 50000 & 0.00401 & 0.98566 & 440 & 100 \\
\hline 47 & 55 & 55 & 45 & 50000 & 0.00318 & 0.98872 & 441 & 105 \\
\hline 48 & & & 55 & 50000 & 0.00429 & 0.98448 & 440 & 102 \\
\hline
\end{tabular}

Gambar 11. History JST Pada 12 MP

Tanjungan, et., al (Perbandingan Tingkat Akurasi Pengenalan Kadar Semen dan Pasir pada Campuran Kering Berdasarkan Tingkat Resolusi Kamera Dengan Metode Pengenalan JST) 
Berdasarkan Gambar 9 (A) pada resolusi 3MP dapat dilihat hasil terbaik pada saat pengujian data latih dan data uji. Layer 1 dan 2 diambil 3 terbaik dan Layer 3 diambil 1 terbaik yang dapat dilihat pada Tabel 2 .

Tabel 2. Layer Terbaik pada 3MP

\begin{tabular}{|c|c|c|c|c|c|c|c|c|}
\hline \multirow[b]{2}{*}{ No } & \multicolumn{3}{|c|}{ Banyak Neuron } & \multirow[b]{2}{*}{ Epoch } & \multirow[b]{2}{*}{ Performance } & \multirow[b]{2}{*}{$\mathbf{R}$} & \multicolumn{2}{|c|}{$\begin{array}{l}\text { Banyak } \\
\text { Dikenali }\end{array}$} \\
\hline & $\begin{array}{c}\text { Layer } \\
1\end{array}$ & $\begin{array}{c}\text { Layer } \\
2\end{array}$ & $\begin{array}{c}\text { Layer } \\
\mathbf{3}\end{array}$ & & & & $\begin{array}{l}\text { Data } \\
\text { Latih }\end{array}$ & $\begin{array}{c}\text { Data } \\
\text { Uji }\end{array}$ \\
\hline 1 & 25 & - & - & 50000 & 0.0544 & 0.7813 & 223 & 74 \\
\hline 2 & 40 & - & - & 50000 & 0.0498 & 0.80169 & 224 & 77 \\
\hline 3 & 50 & - & - & 50000 & 0.0462 & 0.81756 & 222 & 75 \\
\hline 4 & & 40 & - & 50000 & 0.0129 & 0.95331 & 335 & 76 \\
\hline 5 & & 50 & - & 50000 & 0.0132 & 0.95181 & 343 & 75 \\
\hline 6 & 50 & 40 & - & 50000 & 0.0118 & 0.95728 & 328 & 71 \\
\hline 7 & 40 & 50 & 50 & 50000 & 0.00739 & 0.97342 & 431 & 76 \\
\hline
\end{tabular}

Berdasarkan dari 3 hidden layer, hasil terbaik yang diperoleh terdiri dari 40 neuron pada layer 1, 50 neuron pada layer 2, 50 neuron pada layer 3, Epoch sebesar 50000, Performance sebesar 0.00739, R sebesar 0.97342, data latih yang dikenali sebesar 431, dan data uji yang dikenali sebesar 76 sebagai model JST pada campuran kering dengan resolusi kamera sebesar 3MP.

Berdasarkan Gambar 9 (B) pada resolusi 5MP dapat dilihat hasil terbaik pada saat pengujian data latih dan data uji. Layer 1 dan 2 diambil 3 terbaik dan Layer 3 diambil 1 terbaik yang dapat dilihat pada Tabel 3 .

Tabel 3. Layer Terbaik pada 5MP

\begin{tabular}{|c|c|c|c|c|c|c|c|c|}
\hline \multirow{2}{*}{ No } & \multicolumn{3}{|c|}{ Banyak Neuron } & \multirow{2}{*}{ Epoch } & \multirow{2}{*}{ Performance } & \multirow{2}{*}{$\mathbf{R}$} & \multicolumn{2}{|c|}{ Banyak Dikenali } \\
\hline & $\begin{array}{c}\text { Layer } \\
1\end{array}$ & $\begin{array}{c}\text { Layer } \\
2\end{array}$ & $\begin{array}{c}\text { Layer } \\
\mathbf{3}\end{array}$ & & & & $\begin{array}{l}\text { Data } \\
\text { Latih }\end{array}$ & $\begin{array}{c}\text { Data } \\
\text { Uji }\end{array}$ \\
\hline 1 & 25 & - & - & 50000 & 0.0332 & 0.87247 & 306 & 76 \\
\hline 2 & 35 & - & - & 50000 & 0.0339 & 0.87018 & 294 & 83 \\
\hline 3 & 75 & - & - & 50000 & 0.0289 & 0.89044 & 307 & 88 \\
\hline 4 & 25 & 75 & - & 50000 & 0.0121 & 0.95577 & 397 & 91 \\
\hline 5 & 35 & 75 & - & 50000 & 0.0157 & 0.9423 & 392 & 98 \\
\hline 6 & 75 & 75 & - & 50000 & 0.0155 & 0.94265 & 371 & 92 \\
\hline 7 & 75 & 75 & 35 & 50000 & 0.0111 & 0.95969 & 392 & 102 \\
\hline
\end{tabular}

Berdasarkan dari 3 hidden layer, hasil terbaik yang diperoleh terdiri dari 75 neuron pada layer 1, 75 neuron pada layer 2, 35 neuron pada layer 3, Epoch sebesar 50000, Performance 
sebesar 0.0111, R sebesar 0.95969, data latih yang dikenali sebesar 392, data uji yang dikenali sebesar 102 sebagai model JST pada campuran kering dengan resolusi kamera sebesar 5MP.

Berdasarkan Gambar 10 (C) pada resolusi 8MP dapat dilihat hasil terbaik pada saat pengujian data latih dan data uji. Layer 1 dan 2 diambil 3 terbaik dan Layer 3 diambil 1 terbaik yang dapat dilihat pada Tabel 4 .

Tabel 4. Layer Terbaik pada 8MP

\begin{tabular}{|c|c|c|c|c|c|c|c|c|}
\hline \multirow{2}{*}{ No } & \multicolumn{3}{|c|}{ Banyak Neuron } & \multirow{2}{*}{ Epoch } & \multirow{2}{*}{ Performance } & \multirow{2}{*}{$\mathbf{R}$} & \multicolumn{2}{|c|}{$\begin{array}{c}\text { Banyak } \\
\text { Dikenali }\end{array}$} \\
\hline & $\begin{array}{c}\text { Layer } \\
1\end{array}$ & $\begin{array}{c}\text { Layer } \\
2\end{array}$ & $\begin{array}{c}\text { Layer } \\
3\end{array}$ & & & & $\begin{array}{l}\text { Data } \\
\text { Latih }\end{array}$ & $\begin{array}{c}\text { Data } \\
\text { Uji }\end{array}$ \\
\hline 1 & 20 & - & - & 50000 & 0.0572 & 0.76811 & 211 & 87 \\
\hline 2 & 30 & - & - & 50000 & 0.0522 & 0.79105 & 231 & 78 \\
\hline 3 & 40 & - & - & 50000 & 0.0478 & 0.81022 & 225 & 73 \\
\hline 4 & 20 & 30 & - & 50000 & 0.0209 & 0.92213 & 345 & 80 \\
\hline 5 & 20 & 40 & - & 50000 & 0.0215 & 0.91945 & 355 & 78 \\
\hline 6 & 40 & 40 & - & 50000 & 0.0203 & 0.92456 & 353 & 82 \\
\hline 7 & 20 & 40 & 20 & 50000 & 0.0135 & 0.95156 & 375 & 85 \\
\hline
\end{tabular}

Berdasarkan 3 hidden layer, hasil terbaik yang diperoleh terdiri dari 20 neuron pada layer 1, 40 neuron pada layer 2, 20 neuron pada layer 3, Epoch sebesar 50000, Performance sebesar 0.0135 , R sebesar 0.95156 , data latih yang dikenali sebesar 375 , data uji yang dikenali sebesar 85 sebagai model JST pada campuran kering dengan resolusi kamera sebesar 8MP.

Berdasarkan Gambar 10 (D) pada resolusi 10MP dapat dilihat hasil terbaik pada saat pengujian data latih dan data uji. Layer 1 dan 2 diambil 3 terbaik dan Layer 3 diambil 1 terbaik yang dapat dilihat pada Tabel 5 .

Tabel 5. Layer Terbaik pada 8MP

\begin{tabular}{|c|c|c|c|c|c|c|c|c|}
\hline \multirow{2}{*}{ No } & \multicolumn{3}{|c|}{ Banyak Neuron } & \multirow{2}{*}{ Epoch } & \multirow{2}{*}{ Performance } & \multirow[b]{2}{*}{$\mathbf{R}$} & \multicolumn{2}{|c|}{$\begin{array}{l}\text { Banyak } \\
\text { Dikenali }\end{array}$} \\
\hline & $\begin{array}{c}\text { Layer } \\
1\end{array}$ & $\begin{array}{c}\text { Layer } \\
2\end{array}$ & $\begin{array}{c}\text { Layer } \\
\mathbf{3}\end{array}$ & & & & $\begin{array}{l}\text { Data } \\
\text { Latih }\end{array}$ & $\begin{array}{c}\text { Data } \\
\text { Uji }\end{array}$ \\
\hline 1 & 25 & - & - & 50000 & 0.0484 & 0.80722 & 231 & 67 \\
\hline 2 & 30 & - & - & 50000 & 0.0496 & 0.80139 & 236 & 70 \\
\hline 3 & 35 & - & - & 50000 & 0.0475 & 0.8114 & 247 & 68 \\
\hline 4 & 25 & 35 & - & 50000 & 0.0175 & $\mathbf{0 . 9 3 5 5 5}$ & 373 & 73 \\
\hline 5 & 30 & 30 & - & 50000 & 0.0197 & 0.9266 & 368 & 67 \\
\hline 6 & 35 & 30 & - & 50000 & 0.021 & 0.9217 & 357 & 68 \\
\hline 7 & 35 & 30 & 30 & 50000 & 0.00891 & 0.96834 & 405 & 77 \\
\hline
\end{tabular}

Berdasarkan 3 hidden layer, hasil terbaik yang diperoleh terdiri dari 35 neuron pada layer 1, 30 neuron pada layer 2, 30 neuron pada layer 3, Epoch sebesar 50000, Performance 
sebesar 0.00891 , R sebesar 0.95834 , data latih yang dikenali sebesar 405, data uji yang dikenali sebesar 77 sebagai model JST pada campuran kering dengan resolusi kamera sebesar 10MP.

Berdasarkan Gambar 11 pada resolusi 12MP dapat dilihat hasil terbaik pada saat pengujian data latih dan data uji. Layer 1 dan 2 diambil 3 terbaik dan Layer 3 diambil 1 terbaik yang dapat dilihat pada Tabel 6 .

Tabel 6. Layer Terbaik pada 8MP

\begin{tabular}{|c|c|c|c|c|c|c|c|c|}
\hline \multirow{2}{*}{ No } & \multicolumn{3}{|c|}{ Banyak Neuron } & \multirow[b]{2}{*}{ Epoch } & \multirow{2}{*}{ Performance } & \multirow[b]{2}{*}{$\mathbf{R}$} & \multicolumn{2}{|c|}{$\begin{array}{l}\text { Banyak } \\
\text { Dikenali }\end{array}$} \\
\hline & $\begin{array}{c}\text { Layer } \\
1\end{array}$ & $\begin{array}{c}\text { Layer } \\
2\end{array}$ & $\begin{array}{c}\text { Layer } \\
\mathbf{3}\end{array}$ & & & & $\begin{array}{l}\text { Data } \\
\text { Latih }\end{array}$ & $\begin{array}{c}\text { Data } \\
\text { Uji }\end{array}$ \\
\hline 1 & 35 & - & - & 50000 & 0.0286 & 0.89109 & 296 & 85 \\
\hline 2 & 45 & - & - & 50000 & 0.0259 & 0.90236 & 309 & 91 \\
\hline 3 & 55 & - & - & 50000 & $\mathbf{0 . 0 3 0 7}$ & 0.88255 & 298 & 84 \\
\hline 4 & 35 & 35 & - & 50000 & 0.0069 & 0.97579 & 432 & 97 \\
\hline 5 & 45 & 35 & - & 50000 & 0.00482 & 0.98277 & 431 & 92 \\
\hline 6 & 55 & 55 & - & 50000 & 0.00535 & 0.98063 & 438 & 96 \\
\hline 7 & 55 & 55 & 45 & 50000 & 0.00318 & 0.98872 & 441 & 105 \\
\hline
\end{tabular}

Berdasarkan 3 hidden layer, hasil terbaik yang diperoleh terdiri dari 55 neuron pada layer 1, 55 neuron pada layer 2, 45 neuron pada layer 3, Epoch sebesar 50000, Performance sebesar 0.00318 , R sebesar 0.98872 , data latih yang dikenali sebesar 441 , data uji yang dikenali sebesar 105 sebagai model JST pada campuran kering dengan resolusi kamera sebesar 12MP.

\subsection{Pengujian Arsitektur JST dan Hasil}

Tahap ini melakukan pengujian arsitektur JST menggunakan nilai dari hasik ekstrasi fitur yang terdiri dari 6 nilai antara lain nilai Entropy, Standard Deviation, Contrast, Angular Second Moment(ASM)/ Homogeneity, Correlation, dan Inverse Different Moment(IDM)/ Energy . Data uji yang digunakan sebanyak berjumlah 120, pengujian dilakukan dengan menggunakan rancangan GUI yang telah dibuat pada aplikasi MATLAB seperti yang dapat dilihat pada Gambar 12.

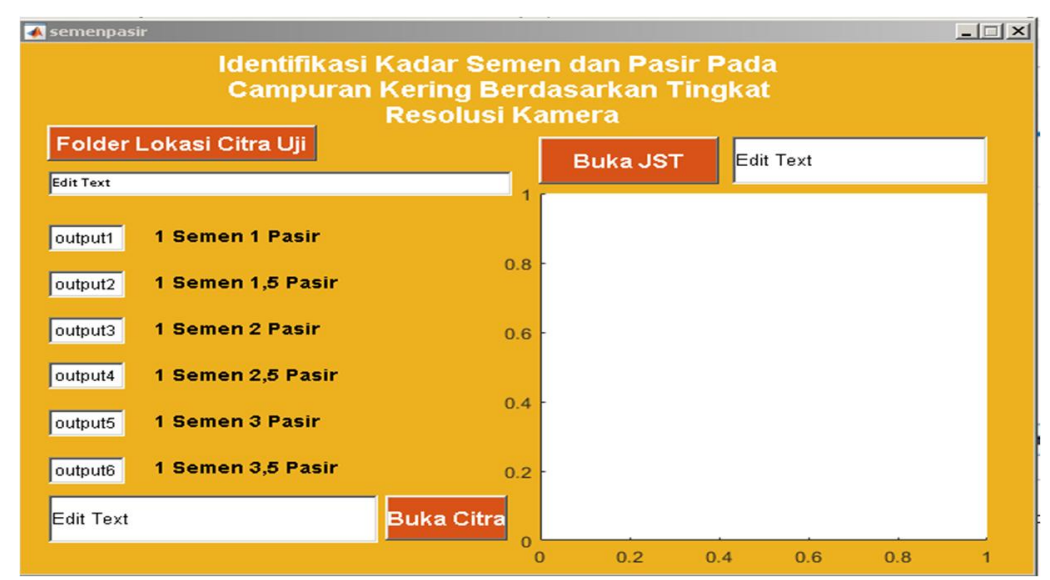

Gambar 12. Bentuk GUI Pengujian Jenis Campuran

Tanjungan, et., al (Perbandingan Tingkat Akurasi Pengenalan Kadar Semen dan Pasir pada Campuran Kering Berdasarkan Tingkat Resolusi Kamera Dengan Metode Pengenalan JST) 
Tahap ini melakukan penentuan hasil pengujian terhadap arsitektur Jaringan Syaraf Truan, perhitungan akurasi dihitung menggunakan rumus akurasi seperti berikut:

$$
\text { Akurasi }=\frac{\sum \text { identifikasi benar }}{\sum \text { identifikasi }} \times 100 \%
$$

Hasil pengujian berdasarkan data uji dan hasilnya dapat dilihat pada Tabel 7, Tabel 8 , Tabel 9, Tabel 10, Tabel 11.

Tabel 7. Hasil Pengujian Pada 3MP

\begin{tabular}{|c|c|c|c|c|}
\hline No & Jenis Campuran & Data Uji & $\begin{array}{c}\text { Data } \\
\text { Dikenali }\end{array}$ & $\begin{array}{c}\text { Data Tidak } \\
\text { Dikenali }\end{array}$ \\
\hline 1 & 1 semen 1 pasir & 20 & 20 & 0 \\
\hline 2 & 1 semen 1,5 pasir & 20 & 13 & 7 \\
\hline 3 & 1 semen 2 pasir & 20 & 8 & 12 \\
\hline 4 & 1 semen 2,5 pasir & 20 & 9 & 11 \\
\hline 5 & 1 semen 3 pasir & 20 & 10 & 10 \\
\hline 6 & 1 semen 3,5 pasir & 20 & 16 & 4 \\
\hline
\end{tabular}

Tabel 8. Hasil Pengujian pada 5MP

\begin{tabular}{|c|c|c|c|c|}
\hline No & Jenis Campuran & Data Uji & Data Dikenali & $\begin{array}{c}\text { Data Tidak } \\
\text { Dikenali }\end{array}$ \\
\hline 1 & 1 semen 1 pasir & $\mathbf{2 0}$ & 15 & 5 \\
\hline 2 & 1 semen 1,5 pasir & $\mathbf{2 0}$ & 17 & $\mathbf{3}$ \\
\hline 3 & 1 semen 2 pasir & $\mathbf{2 0}$ & $\mathbf{2 0}$ & $\mathbf{0}$ \\
\hline 4 & 1 semen 2,5 pasir & $\mathbf{2 0}$ & $\mathbf{2 0}$ & $\mathbf{0}$ \\
\hline 5 & 1 semen 3 pasir & $\mathbf{2 0}$ & $\mathbf{1 0}$ & $\mathbf{1 0}$ \\
\hline 6 & 1 semen 3,5 pasir & $\mathbf{2 0}$ & $\mathbf{2 0}$ & $\mathbf{0}$ \\
\hline
\end{tabular}

Tabel 9. Hasil Pengujian pada 8MP

\begin{tabular}{|c|c|c|c|c|}
\hline No & Jenis Campuran & Data Uji & Data Dikenali & $\begin{array}{c}\text { Data } \\
\text { Tidak } \\
\text { Dikenali }\end{array}$ \\
\hline 1 & 1 semen 1 pasir & 20 & 19 & 1 \\
\hline 2 & 1 semen 1,5 pasir & 20 & 11 & 9 \\
\hline 3 & 1 semen 2 pasir & 20 & 15 & 5 \\
\hline 4 & 1 semen 2,5 pasir & 20 & 9 & 11 \\
\hline 5 & 1 semen 3 pasir & 20 & 13 & 7 \\
\hline 6 & 1 semen 3,5 pasir & 20 & 18 & 2 \\
\hline & TOTAL & 120 & 85 & 35 \\
\hline
\end{tabular}


Tabel 10. Hasil Pengujian pada 10MP

\begin{tabular}{|c|c|c|c|c|}
\hline No & Jenis Campuran & Data Uji & Data Dikenali & $\begin{array}{c}\text { Data Tidak } \\
\text { Dikenali }\end{array}$ \\
\hline 1 & 1 semen 1 pasir & 20 & 15 & 5 \\
\hline 2 & 1 semen 1,5 pasir & 20 & 17 & 3 \\
\hline 3 & 1 semen 2 pasir & 20 & 13 & 7 \\
\hline 4 & 1 semen 2,5 pasir & 20 & 10 & 10 \\
\hline 5 & 1 semen 3 pasir & 20 & 15 & 5 \\
\hline 6 & 1 semen 3,5 pasir & 20 & 7 & 13 \\
\hline
\end{tabular}

Tabel 11. Hasil Pengujian pada 12MP

\begin{tabular}{|c|c|c|c|c|c|}
\hline \multirow{2}{*}{ No } & Jenis Campuran & Data Uji & Data Dikenali & $\begin{array}{c}\text { Data Tidak } \\
\text { Dikenali }\end{array}$ \\
\hline 1 & 1 semen 1 pasir & 20 & 20 & 0 \\
\hline 2 & 1 semen 1,5 pasir & 20 & 20 & 0 \\
\hline 3 & 1 semen 2 pasir & 20 & 17 & 3 \\
\hline 4 & 1 semen 2,5 pasir & 20 & 15 & 5 \\
\hline 5 & 1 semen 3 pasir & 20 & 13 & 7 \\
\hline 6 & 1 semen 3,5 pasir & 20 & 20 & 0 \\
\hline
\end{tabular}

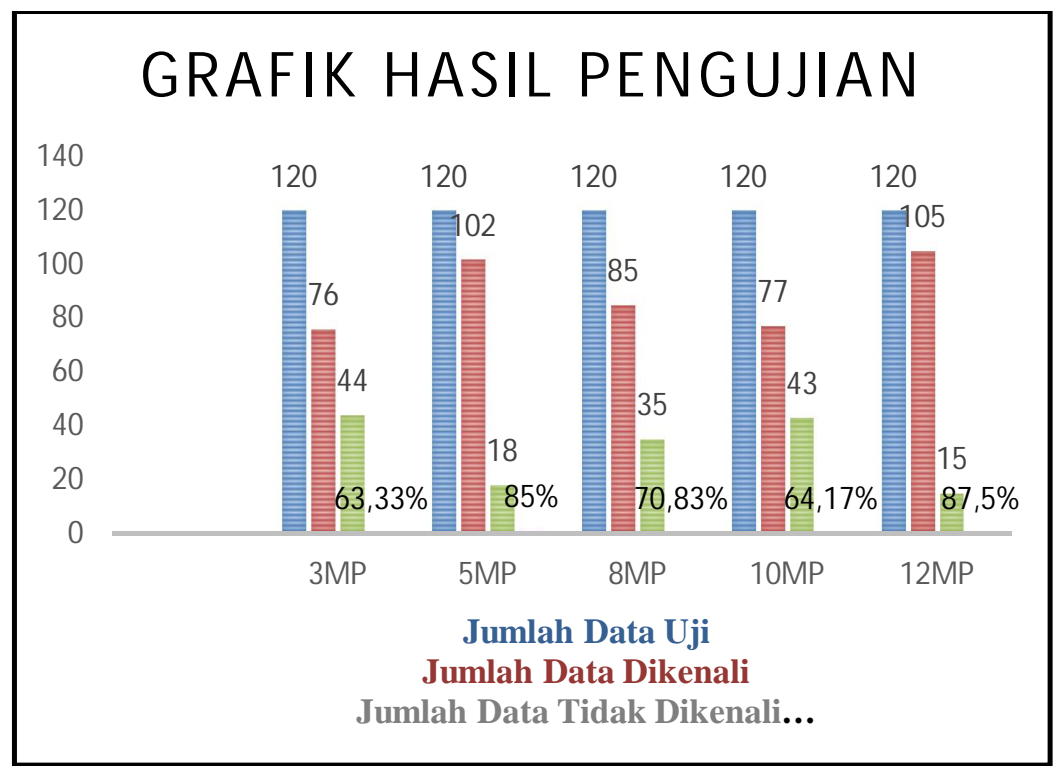

Gambar 13. Grafik Hasil Pengujian

Untuk setiap jenis resolusi kamera yang digunakan, masing-masing data yang dikenali untuk 6 jenis campuran kering akan dihitung untuk tingkat akurasinya. Pada resolusi kamera $3 \mathrm{MP}$ diperoleh tingkat akurasi sebesar 63,33\%. Pada resolusi kamera 5MP diperoleh tingkat akurasi sebesar $85 \%$. Pada resolusi kamera 8MP diperoleh tingkat akurasi sebesar 70,83\%. Pada resolusi kamera 10MP diperoleh tingkat akurasi sebesar 64,167\%. Pada resolusi kamera 12MP diperoleh tingkat akurasi sebesar $87,5 \%$. 


\section{KESIMPULAN}

Berdasarkan hasil penelitian yang dilakukan, berikut beberapa kesimpulan yang dapat disimpulkan:

1. Selama penelitian dapat memahami cara mengumpulkan data, dimulai dari pembuatan objek dengan mencampurkan semen dan pasir sesuai dengan takaran, pemotretan dengan resolusi kamera yang berbeda beda, pengambilan nilai ekstrasi fitur dengan GLCM, pengujian JST, dan terakhir diperoleh hasil akhir akurasi terbaik.

2. Selama penelitian yang telah dilakukan menggunakan 5 jenis tingkat resolusi kamera antara lain 3MP, 5MP, 8MP, 10MP, 12MP dengan jarak yang digunakan selama pemotretan $\pm 9 \mathrm{~cm}$. Perhitungan akurasi dihitung berdasarkan data uji yang dikenali pada 3 hidden layer terbaik yang dapat dilihat dari tabel 4.1 hingga tabel 4.5, yang dimana resolusi kamera 12MP memiliki hasil pengenalan pada jenis campuran kering terbaik dibandingkan dengan resolusi kamera lainnya.

3. Resolusi kamera 12MP merupakan resolusi kamera terbaik dalam pengenalan jenis campuran kering dengan hasil pengenalan sebanyak 105 dari 120 data uji. Hasil perhitungan tangkat akurasi diperoleh sebesar $87,5 \%$ dan merupakan hasil perhitungan yang paling tinggi dibandingkan dengan resolusi kamera lainnya.

\section{SARAN}

Berdasarkan kesimpulan yang telah diuraikan sebelumnya, terdapat beberapa saran untuk penelitian selanjutnya sehingga bisa memperoleh hasil yang lebih baik, antara lain:

1. Penelitian ini menggunakan 6 jenis campuran kering sehingga belum diketahui hasil penelitian dengan menggunakan lebih dari 6 jenis campuran.

2. Penelitian ini menggunakan ekstrasi fitur GLCM(Gray Level Co-Occurrence Matrix), sehingga belum diketahui hasil penelitian dengan menggunakan ekstrasi fitur yang berbeda.

3. Penelitian ini menggunakan metode penelitian Jaringan Syaraf Tiruan, sehingga belum diketahui hasil penelitian dengan metode penelitian yang berbeda.

4. Penelitian ini menggunakan tingkat resolusi kamera 3MP, 5MP, 8MP, 10MP, 12MP, sehingga belum diketahui hasil penelitian dengan tingkat resolusi lainnya.

5. Diharapkan menggunakan pencahayaan lampu di dalam box atau kotak, sehingga pencahayaan tidak mempengaruhi hasil pemotretan.

6. Diharapkan adanya pengembangan aplikasi kedepannya menggunakan software pemrograman yang berbeda..

\section{DAFTAR PUSTAKA}

[1] Fuad, 2020, "Pengaruh Pemakaian Semen dan Pasir yang Berbeda Terhadap Kuat Tekan Beton," Jurnal Desiminasi Teknologi Fakultas Teknik Universitas Tridinanti Palembang , vol. 53, pp. 1689-1699.

[2] R. D. I. R. \&. T. R. Gasim. 2020, "Identifikasi Kadar Semen dan Pasir Melalui Citra Permukaan Menggunakan Teknik Blok Citra," JATISI (Jurnal Teknik Informatika Dan Sistem Informasi), vol. 7, no. 2, pp. 188-199.

[3] Kelvin Bun, Hurnaningsih. 2018, "Identifikasi Telur Retak Menggunakan Metode Jaringan Syaraf Tiruan Berdasarkan Tekstur Telur," 183-192.

Tanjungan, et., al (Perbandingan Tingkat Akurasi Pengenalan Kadar Semen dan Pasir pada Campuran Kering Berdasarkan Tingkat Resolusi Kamera Dengan Metode Pengenalan JST) 
Jurnal Algoritme

Vol. 1, No. 2, April 2021, Hal. 168-183

[4] F. P. A. P. B. T. \&. K. Amanullah. 2018, "Deteksi Motif Batik Menggunakan Ekstrasi Fitur Dan Jaringan Syaraf Tiruan," pp. 31-36.

[5] I. R. R. K. D. \&. B. W. Hidayatno. 2008, "Identifikasi Tanda-tanda Menggunakan Jaringan Saraf Tiruan Perambatan-Balik (Backpropagation)," pp. 100-106. 